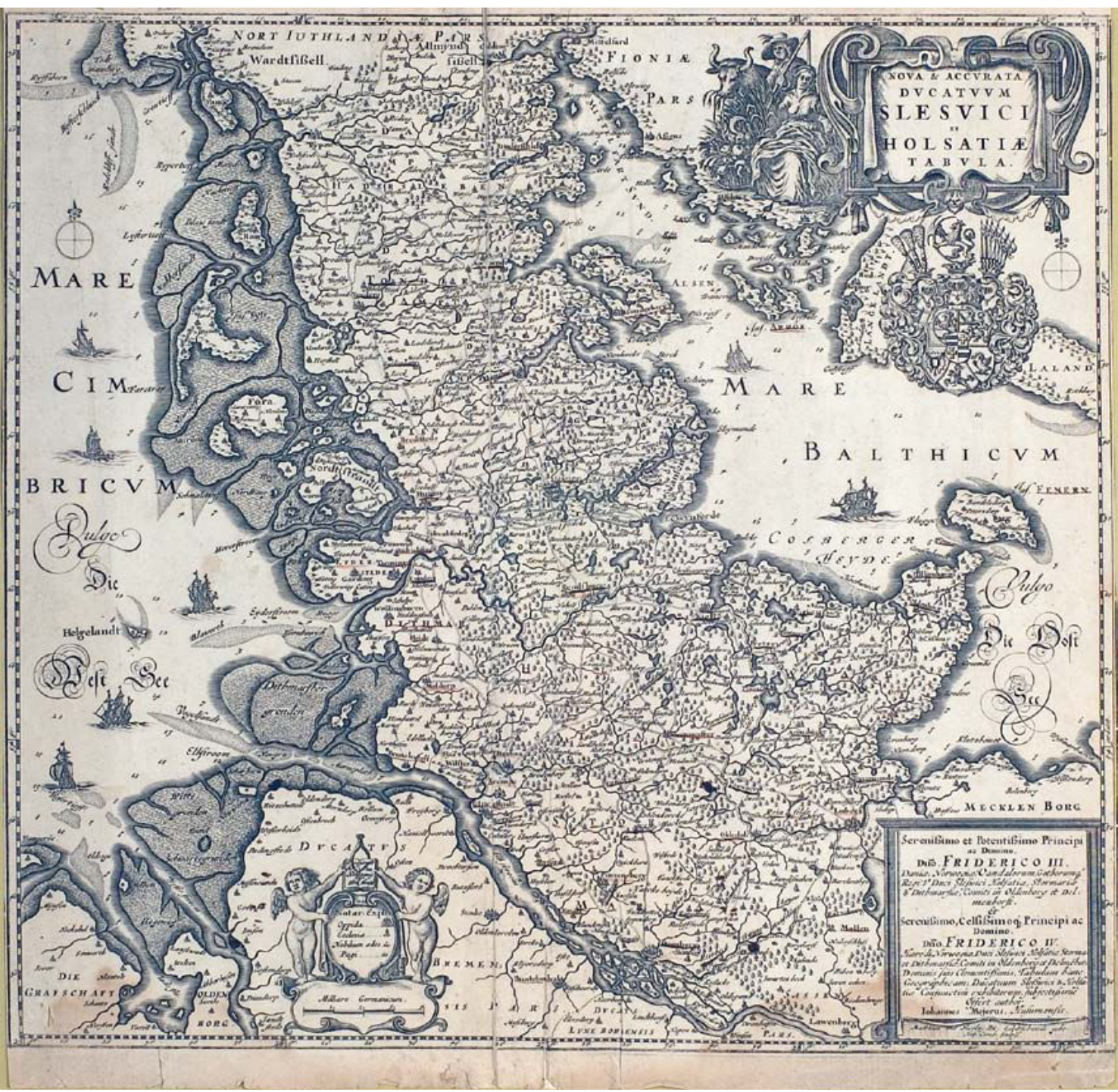

Hertugdømmet Slesvig omkring 1650. Byen Garding findes midt på halvøen og Landskabet Ejdersted, til venstre for kortets midte. Foto: Arkivet ved Dansk Centralbibliotek for Sydslesvig.

\section{Hor og sladder}

- en kirkebodssag fra Garding

Af Karsten Merrald Sørensen

I begyndelsen af 1600-tallet udspandt der sig en strid i Garding ved Ejdersted. Stridens parter var på den ene side borgeren Peter Thomsen, og på den anden side kirken og de lokale præster. Præsterne ville ikke lade Thomsen gå til alters og modtage nadveren, fordi han havde bedrevet hor. Derved havde han forbrudt sig mod det sjette bud. Den gottorpske hertug Johan Adolf var stærkt involveret i sagen, idet han pålagde præsterne, at de skulle lade Thomsen modtage nadveren. I denne artikel analyseres sagsforløbet med et særligt fokus på forholdet mellem fyrstemagten og kirken få årtier efter at reformationen var gennemført i Danmark og hertugdømmerne.

I starten af 1600-årene rasede der en sag i byen Garding omkring kirketugt, som kom til at involvere alle led i den kirkelige administration efter reformationen i hertugdømmet Slesvig. Reformationen var officielt blevet indført i Slesvig med kirkeordinansen af 1542. Herefter var det op til hertugerne at organisere og administrere kirken i deres områder i det omfang, hertugen kunne komme overens med sine undersåtter derom. At hertugen var blevet den øverste ansvarlige for kirkens organisation betød ikke, at han var blevet egenmægtig. Han støttede sig til rådgivere, som havde kendskab til kirken og til gejstlige forhold. I det daglige fungerede kirken med begrænset indblanding fra hertugens side, han blev fortrinsvis inddraget, når der var problemer. ${ }^{1}$

Problemer var der i høj grad i Garding i foråret og den tidlige sommer i året 1602. En sag omkring kirketugt brød ud i byen i hertugdømmet Slesvig. Eller mere præcist i den del af hertugdømmet, som siden er blevet kendt som hertugdømmet Slesvig-Holsten-Gottorp. Striden stod mellem præsterne i Garding i landskabet Ejdersted og en borger i byen. Sagen kom til at involvere såvel den kirkelige som den verdslige myndighed.

Der findes 14 dokumenter i en udgivet brevsamling tilhørende provst Johannes Pistorius, der ridser sagen op. ${ }^{2}$ Denne brevsamling findes i original på Det Kongelige Bibliotek i København, men er udgivet og oversat af A. Andersen for Historisk Samfund for Sønderjylland i 1971. Samlingen består af ca. 400 breve, fortrinsvis på latin. De er skrevet i perioden fra 1541-1614. De sidste par breve omtaler kun Johannes Pisto- 
rius, da han selv døde i 1605. Langt de fleste breve er tilsendt Johannes Pistorius, mens 59 af brevene er skrevet af provsten personligt. Alle breve er derpå afskrevet enten af Johannes Pistorius selv eller af hans søn, Theodor, i brevbogen.

Stridigheden i 1602 indledes med, at præsterne i Garding afviste at lade borgeren Peter Thomsen, hans hustru og deres børn gå til alters for at modtage den hellige nadver. De kunne ikke få lov til at gå til alters, da Peter Thomsen var blevet anklaget af en række kvinder for at bedrive hor.

Kirkelovgivningen var klar omkring fremgangsmåden i forbindelse med at gå til alters. Man måtte ikke modtage nadveren med et urent hjerte. Derfor skulle man skrifte inden nadvergangen. Det ville der normalt ikke være noget $\mathrm{i}$ vejen for, men da Peter Thomsen stod anklaget for at bedrive hor, havde han forbrudt sig mod det sjette bud. Da det var offentligt kendt, var det også en offentlig synd, der krævede en offentlig kirkebod. Det vil sige et offentligt skriftemål. Denne sag endte hurtigt med at blive en principsag på allerhøjeste niveau, hvor Peter Thomsen efterhånden blev til en bifigur i spillet mellem hertugen som kirkefyrste og gejstligheden, der både skulle være tro mod kirkeordinansen og over for hertugen, som de havde svoret en embeds- og troskabsed til. Denne sag om hor kom dermed til at teste forholdet mellem fyrsten og gejstligheden, der overordnet set havde et fælles mål om at disciplinere befolkningen til at blive gode kristne borgere, men som i de enkelte lokale sager kunne have vidt forskellige holdninger, og hvem vinder så? Skal en præst følge kirkeordinansen i alle henseender, eller skal en præst følge sin fyrste, selv når befalingerne går imod kirkelovgivningen?

De første ca. hundrede år efter reformationen var en brydningstid, hvor moderne nationer efterhånden opstod, og hvor fyrsterne søgte at ensrette befolkningernes konfession. Konfessionen var den trosretning, en person tilhørte. Dette kunne eksempelvis være den evangelsklutherske tro, den katolske tro eller den calvinistiske tro. Disse emner er noget, som historikere har diskuteret $\mathrm{i}$ årevis, og forskningstraditionen kaldes for konfessionaliseringen. ${ }^{3}$ Denne beskæftiger sig med tiden efter reformationen, hvor konfessionerne rundt omkring i Europa ændrede sig. I Nordeuropa blev landsherren, kongen eller hertugen, kirkefyrste efter reformationen og søgte at opbygge sin stat med kun én tilladt konfession. Konfessionaliseringen er oprindeligt et tysk forskningsbegreb, der har inspireret mange danske historikere og kirkehistorikere til at tolke både danske og slesvigske eksempler ud fra de tyske konfessionaliseringsteorier. Der har været forskellige fokuseringer og tolkninger blandt de tyske teoretikere. Disse forskelligheder kan også ses i de danske værker. Her er Mikkel Leth Jespersen blandt de seneste danske historikere, der har brugt dele af den tyske konfessionaliseringsforskning som forklaringsramme og som diskussion i forhold til lokalsamfundets indflydelse på og rolle i statsopbygningen og konfessionaliseringen af samfundet. ${ }^{4}$ Enighed er der dog om, at kirkedisciplinen var yderst vigtig i tiden med konfessionaliseringen, og kirketugten havde i særdeleshed sit sigte rettet mod at opdrage befolkningen til at blive gode kristne borgere. I kirkens øjne skulle man derfor gøre bod, når man, som Peter Thomsen, eksempelvis havde bedrevet hor. Lad os dog først se på, hvad det offentlige skriftemål var for en størrelse.

\section{Det offentlige skriftemål}

Reformationen blev officielt indført med de nye kirkeordinanser. Kongeriget Danmark fik sin i 1537 og reviderede den i 1539, mens hertugdømmerne Slesvig og Holsten fik deres i 1542. Både den danske og den slesvig-holstenske kirkeordinans var i stort omfang præget af den lutherske reformator Johan Bugenhagen. Kirkeordinanserne nyordnede

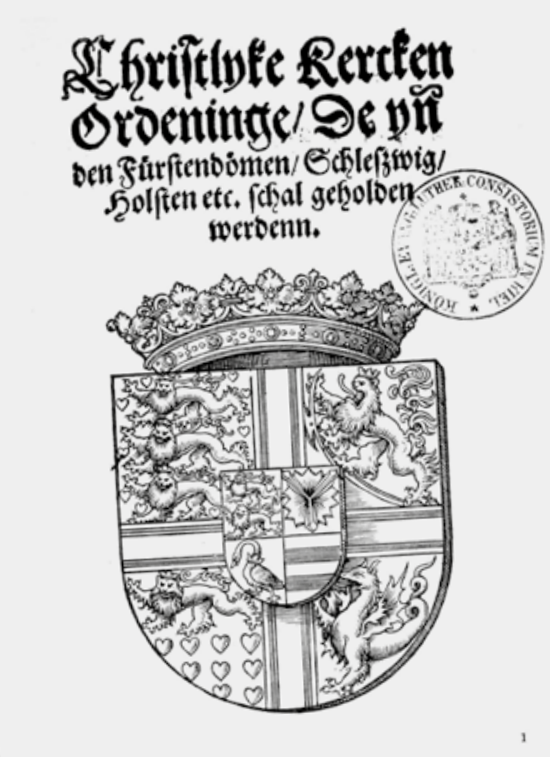

Forsiden til den slesvig-holstenske kirkeordinans 1542. Foto: Karsten M. Sørensen. 
kirkerne i Danmark og Slesvig efter et luthersk mønster. I ordinanserne blev udøvelsen af den lutherske kristendom lagt i officielle rammer. ${ }^{5}$ Landsherren var nu kirkefyrste, og han havde det øverste ansvar for folkets tro. Kirkeordinanserne blev i de følgende århundreder løbende suppleret af forordninger og lovtekster, der uddybede reglerne for religionens udøvelse.

I kirkeordinansen af 1542 blev det således også beskrevet, at personer der begik incest eller andre offentlige synder, samt alle der forbrød sig mod gudstjenesten eller spottede og foragtede den og nadveren, begik æresbrud eller gjorde sig skyldig i andre grove laster. Først efter det offentlige skriftemål kunne de igen få adgang til nadveren efter den klassiske devise: "Til den åbenbare synd hører også den åbenbare absolution. Hvad der er sket i hemmelighed skal også gives en hemmelig absolution." ${ }^{\prime 6}$ Det offentlige skriftemål skulle finde sted efter præstens prædiken, når højmessen var forbi, men mens menigheden endnu var til stede. ${ }^{7}$

Nadveren var et helligt sakramente, hvor man modtog Jesu kød og blod, fik en forsmag på Guds nåde og blev et medlem af det kristne fællesskab. Hvis man modtog nadveren med et urent hjerte risikerede man at blive fortabt. Herudover risikerede præsten, hvis han tillod en uværdig person at modtage nadveren, også sin egen fortabelse sammen med hele menighedens fortabelse. ${ }^{8}$ Det var dermed ikke uvæsentligt, at kirkedisciplinen fandtes. Hensigten med kirkeboden var, at den skulle opbygge en god moral hos den pågældende synder og hos menighedsmedlemmerne, som var vidne til handlingen. Det var især brud på det sjette bud - Du må ikke bryde ægteskabet - der blev takseret til offentlig kirkebod, hvor synderen skulle angre sin handling, modtage præstens formaning og til sidst absolution, hvilket vil sige en kirkelig tilgivelse.

Selve den kirkelige handling bestod i, at præsten først prædikede for synderen. Dette skete foran hele menigheden med synderen stående på gulvet. Derpå skulle præsten spørge synderen, om denne bekendte sine synder. Synderen skulle herefter vende sig mod menigheden og bede om forladelse for den begåede handling. Næste ritual var, at synderen lagde sig på knæ for præsten, som på synderens vegne også bad menigheden om forladelse. Til slut gav præsten endnu en formaning og med håndspålæggelse absolution, hvorefter synderen atter var velkommen ved Herrens bord. Det offentlige skriftemål var ikke blot en religiøs og moralsk opbyggelig handling, men også en begivenhed, der har kunnet interessere og samle sognets medlemmer, som sikkert har været modtagelige for den lokale sladder. Her så lokalsamfundet de dårlige samvittigheder stillet offentligt til skue inde i kirkerummet. ${ }^{9}$ Det er ikke vanskeligt at forestille sig folks snakken efterfølgende.

\section{Det offentlige skriftemål i lokale forhold}

Det offentlige skriftemål opstod ikke med reformationen, men blev også praktiseret i middelalderens kirke. Den blev så videreført af reformationens kirkeordinanser. Kirkens sanktionsapparat fungerede ved siden af den verdslige øvrigheds retshåndhævelse. Der var således ikke tale om, at en kirkelig afstraffelse kunne afværge en verdslig afstraffelse. Kirketugten fungerede ideelt set uafhængigt af det verdslige retssystem. Man kunne ikke blive fritaget for kirketugten blot ved at underkaste sig en verdslig afgørelse. I forbindelse med en religiøs synd, såsom lejermål, altså samleje uden for ægteskab, var der også et verdsligt retsopgør med en fastsat straf, eventuelt i form af en bøde. ${ }^{10}$

Første halvdel af 1600-tallet blev præget af ortodoksien, hvor stat og kirke søgte at disciplinere befolkningen gennem forordninger til at blive gode, fromme og lydige lutheranere - og dermed gode og lydige undersåtter. Fyrstens bevæggrunde for at søge en disciplinering af sine undersåtter var todelt. Dels så fyrsten sig selv som en kristen fyrste, der havde et ansvar over for Gud for forholdene i sit rige, dels krævede skatteopkrævningen og soldaterudskrivningen en lydig befolkning. ${ }^{11}$ Dermed har der i Danmark også ofte været et stort fokus på kirkepolitikken, konfessionaliseringen og kirketugten som noget fyrsten og Kirken brugte, så at sige, oppefra og ned. Når fokus ændres til at se på helt lokale forhold i Danmark i 1600-tallet ses et billede af en fremvoksende statsmagt, som satte sig igennem på undersåtternes bekostning. Statens magt var dog begrænset, specielt i udkantsområderne. ${ }^{12}$

I Sverige kan man desuden se, at de svenske bønder i 1600-tallet havde en levende religiøsitet og var meget deltagende i religionen. Bøndernes form for religiøsitet stemte dog ikke altid overens med den religiøsitet, som kirken og fyrsten gerne så udlevet. Der var en kløft mellem elite- og folkereligion, men samtidig mødtes de to også på visse punkter. Der var en del af kirketugten, som almuen faktisk bakkede op om, samt andre dele som befolkningen stod uforstående overfor. ${ }^{13}$ Bønderne i Sverige beklagede sig således ofte. Eksempelvis var det ikke usædvanligt, at bønderne kom og gik under gudstjenesten, som det passede dem, men hvis præsten forsømte gudstjenesten, så brokkede bønderne sig højlydt. 
Bønderne og kirkeledelsen var dog enige om især ét punkt. Kirken skulle være ren for synder, og man måtte kun modtage nadveren med et rent hjerte. Derfor hændte det i de svenske kirker, og sikkert også i de danske og slesvigske kirker, at der af og til var ballade inde i kirken. Der findes flere beskrivelser af, at folk med et "urent hjerte" på vej mod nadveren korporligt blev hevet væk fra alteret af andre sognebørn. Man måtte ikke gå til alters, hvis ikke man først havde bekendt sine synder i et skriftemål. Dette skete eksempelvis i 1657 i Tunhems kirke nordøst for Göteborg, hvor bonden Anders selv tog affære. Den fjerde juledag 1657 ville en unavngiven bonde gå til nadveren under gudstjenesten, men Anders klemte sig frem mellem menneskerne, da han så det. Anders kom frem til bonden og standsede ham med en besked om, at han skulle afstå fra nadveren denne gang. Dette skabte en del tumult, og præsten blandede sig. Bonden bedyrede, at han ikke havde kendskab til, at han skulle have gjort Anders noget ondt, og præsten lod ham derfor modtage nadveren. Denne håndtering gjorde blot Anders mere vred og han truede derfor præsten med tæv og skældte ham godt ud. Siden rejste præsten sagen ved Skara Domkirke, hvor det kom frem, at Anders beskyldte den unavngivne bonde for at have været utro og have bedraget sin hustru. ${ }^{14}$ Det var derfor Anders' pligt at bremse modparten i at modtage nadveren, når der var en uafklaret sag.

Desværre for Anders var han alene i lige netop denne sag, men 1500og 1600-tallets befolkning ville ikke finde sig i, at alle synder gik ustraffet forbi. De skulle afsluttes rigtigt, inden nadveren kunne modtages. Dette sørgede det offentlige skriftemål blandt andet for. Den lokale forankring i konfessionaliseringen kunne også ses i hertugdømmet Slesvig, nærmere bestemt i hertug Hans den Ældres del af hertugdømmet, i anden halvdel af 1500-tallet, hvor undersåtterne spillede en aktiv rolle i konfessionaliseringen. Dette er blandt andet synligt i de politi- og luksusforordninger, der blev udstedt og rettet mod at opretholde "god politi" og orden. Dette var tilfældet både med forordninger til Nordstrand og Haderslev. Formuleringerne af luksusforordningerne blev skrevet lokalt og siden ophøjet af hertugen. ${ }^{15}$

Et lidt senere eksempel på en kirketugtssag fra kongeriget Danmark kan også fremhæves. Her forsøgte en person også at slippe for at modtage det offentlige skriftemål. Denne sag fandt sted i Hald sogn i starten af 1700-tallet. I Hald kirke lyste præsten Caspar Pedersen Lindenfeldt i 1701 karlen Jens Jensen Bach i band. "Den grove og forargelige synder" havde da ikke været til alters i mere end to år. Præsten havde el- lers givet karlen flere påbud om at modtage et offentligt skriftemål og efterfølgende modtage nadveren, men uden held. Det var en alvorlig sag at blive lyst i band. Den bandlyste blev udelukket fra det kristne fællesskab, og han kunne eksempelvis ikke begraves på kirkegården. Hvis man havde været bandlyst i mere end et år skulle den verdslige øvrighed endda sørge for, at synderen blev landsforvist. ${ }^{16}$ Jens Jensen Bachs forbrydelse bestod i, at han ikke havde været til alters i flere år. Det var ifølge Danske Lov fra 1683 endeligt blevet præciseret, hvor ofte alle skulle modtage alterets sakramente. Mindst én gang om året skulle man modtage nadveren. Straffen for overtrædelse af dette påbud var et offentligt skriftemål. Ifølge præsten hr. Caspars udlægning af sagen, var karlen modvillig og udviste foragt, når han blev påbudt nadvergangen af præsten. Jens Jensen Bach havde dog forståeligt nok en anden udlægning. Han hævdede, at der forelå en konkret konflikt mellem præsten og karlen, hvor hr. Caspar både havde ydmyget og generet ham i en sådan grad, at Jens til sidst valgte at holde sig væk fra kirken. Konflikten havde både omhandlet uenighed omkring tiendebetaling og optøjer i forbindelse med katekismeundervisningen.

I en kirkelig optik var det dog irrelevant, om der kunne være en personlig grund til udeblivelse fra nadveren. Det var hele samfundet og fællesskabet, der kunne blive udsat for Guds vrede, når én udeblev. Det var dog yderst sjældent, at disse sager kom så vidt. Ofte kunne man med trusler om bandlysning lokke de fleste mennesker tilbage i fællesskabet. ${ }^{17}$

Jens Jensen Bach blev som nævnt lyst i band i 1701, men sagen endte ikke hermed. Jens indstævnede præsten for Højesteret på grund af uberettiget brug af kirkens band, og en retslig sag blev indledt. Hele sagen var temmelig omskiftelig. Under sagen skiftede Jens mening og lovede at stille til offentligt skriftemål i Hald kirke, men skiftede igen mening da dagen for dette kom, hvorpå han igen nægtede at skrifte for hr. Caspar offentligt inde i Hald kirke. Derfor blev der halvandet år efter bandlysningen afsagt en dom om landsforvisning af Jens Jensen Bach. Dette skridt fik endelig karlen til at besinde sig, og han lovede at modtage det offentlige skriftemål i Hald kirke. Dette fandt sted i december 1702.

Det var en lang proces, der inddrog mange instanser. I modsætning til sagen fra Garding lykkedes det ikke for Jens Jensen Bach at finde verdslig støtte i sin kamp mod gejstligheden. Han forsøgte sig ellers med et brev til kong Frederik 4., men kongen sendte blot brevet videre til biskop Braem i Aarhus, der naturligt nok støttede præsten i Hald. ${ }^{18}$ Her ca. hundrede år efter sagen i Garding var kirketugten omkring år 
1700 fortsat en fælles sag for gejstligheden og kirkefyrsten, og i dette tilfælde var der enighed mellem dem. Der var lokalt en interesse i at opretholde den almindelige orden, moral og kristelige vandel. Hertugen disponerede ikke over et statsligt apparat i 1500-tallet, der kunne gennemtrumfe beslutninger på lokalt niveau. Det centrale indhold i de fyrstelige forordninger måtte have lokal opbakning. ${ }^{19}$

Denne opbakning kunne kirkefyrsten finde hos befolkningen i sager vedrørende forbrydelser, der krævede et offentligt skriftemål. Kirken blev betragtet som et helligt rum, og den skulle derfor være ren for synder. Man respekterede kirkefreden og kirken skulle være spirituel ren man måtte ikke modtage nadveren med et urent hjerte..$^{20}$ Det offentlige skriftemål i 1600-tallet, og den kirkelige disciplin i det hele taget, ska ses i forhold til en samlet kirkepolitik, der inddrog både de gejstlige ledere og den verdslige kirkefyrste, hertugen i Slesvig. Denne sag fra Garding er ikke unik i sig selv, der kendes allerede til andre kirketugtssager. ${ }^{21}$ Sagen fra Garding er dog særlig, da den foregår meget tidligt den periode, der er kendt som konfessionaliseringen, og den er særlig da den foregår i hertugdømmet Slesvig. De andre kendte sager finder gerne sted efter Christian 4.s kirkedisciplineringsforordning fra 1629 og i kongeriget. Derfor er det meget interessant at se på forløbet i 1602 i Garding. Lad os dog først lige få præsenteret sagens hovedpersoner.

\section{Hovedpersoner i sagen}

På den ene side står gejstligheden, som består af de to præster fra Garding, Peter Aurifaber (Goldschmidt) og Sebastian Meier. Herudover har vi provsten Johannes Pistorius (Becker) og generalprovst Jacob Fabricius den Ældre.

Begge præster fra Garding var i 1602 ældre herrer. Peter Aurifaber (Goldschmidt) blev født i Husum og tiltrådte sit første præsteembede i Keitum allerede i 1542. I 1555 rejste han til Schwesing inden han i 1570 tiltrådte som præst i Garding. Dette embede holdt han til sin død i 1605. Sebastian Meier blev født i Strauszberg i Mark Brandenburg og studerede i Wittenberg. Han kom til Garding i 1573 som skolelærer, og blev i 1576 udnævnt til diakon ved kirken. Denne stilling holdt han også til sin død i 1613. ${ }^{22}$

Johannes Pistorius (Becker) blev født i 1528, ligeledes i Husum. Han studerede i både Lüneburg og København og opholdt sig desuden i Wittenberg. Han var inspireret og præget af reformatoren Philip Me- lanchton. I 1557 tiltrådte han præsteembedet i Tetenbüll og i 1584 blev han udnævnt til provst for landskabet Ejdersted. Han døde i 1605. ${ }^{23}$

Jacob Fabricius den Ældre blev født i Tønder i 1560. Han studerede ved universiteterne i Wittenberg, Helmstedt og Rostock. I $1586 \mathrm{blev}$ han diakon i Tønder. Tre år senere blev han i 1589 hentet til Gottorp Slot af hertug Adolf som hofpræst og provst over Gottorp provsti. Johannes Pistorius (Becker) var blevet tilbudt embedet først, men afslog med henvisning til sin høje alder, hvorefter han foreslog Fabricius i stedet. I år 1600 blev Jacob Fabricius den Ældre udnævnt til generalprovst i hertugdømmet. Han grundlagde på det nærmeste et præstedynasti, da alle seks overlevende sønner selv blev præster. Den ældste søn hed også Jacob Fabricius og blev derfor kaldt den Yngre. Han efterfulgte faderen som generalprovst og generalsuperintendent, som embedet efterhånden kom til at hedde. ${ }^{24}$

På den anden side har vi borgeren fra Garding, Peter Thomsen, og hertug Johan Adolf. Peter Thomsen er stort set ukendt, det er dog ikke så væsentligt i denne sammenhæng. På trods af at han er omdrejningspunktet for sagen, spiller han ikke den store rolle. Vigtigt er det dog, at han havde visse kontakter til hoffet på Gottorp Slot, måske endda direkte til hertugen. Havde det ikke været for disse ukendte kontakter havde sagen formentligt aldrig udviklet sig som den gjorde.

Hertug Johan Adolf blev født i 1575 som den tredje søn af hertug Adolf af Gottorp. De to ældre brødre døde imidlertid hurtigt efter faderen, hvorefter Johan Adolf arvede hertugtitlen og hertugdømmet Slesvig-Holsten-Gottorp. Johan Adolf var en anden type hertug end sin far, hertug Adolf. Denne havde været en krigerisk og håndfast type, mens hertug Johan Adolf var mere civilist, der arbejdede med udbygning af hertugdømmets administration og interesserede sig for kunst, kultur og kirkelige anliggender. Hertug Johan Adolf giftede sig med Augusta, der var søster til kong Christian 4., og herefter udviklede hoffet på Gottorp Slot sig næsten til et kongeligt niveau. I 1597 blev der eksempelvis dagligt bespist 433 mand på slottet. ${ }^{25}$ Hertug Johan Adolf var teologisk set, som det fremgår, ikke enig med hverken den danske konge eller det meste af sit hertugdømme. Han havde et calvinistisk syn på kristendommen. Dette præg fik han gennem sin opdragelse ved hoffet i Hessen. Her blev han også påvirket af de politiske idealer, der var fremme i Hessen. Disse fremelskede styrkelsen af både arveretten og fyrstemagten. I Johan Adolfs tid som hertug af Gottorp gik han efter at styrke magtens centralisation. ${ }^{26}$ 


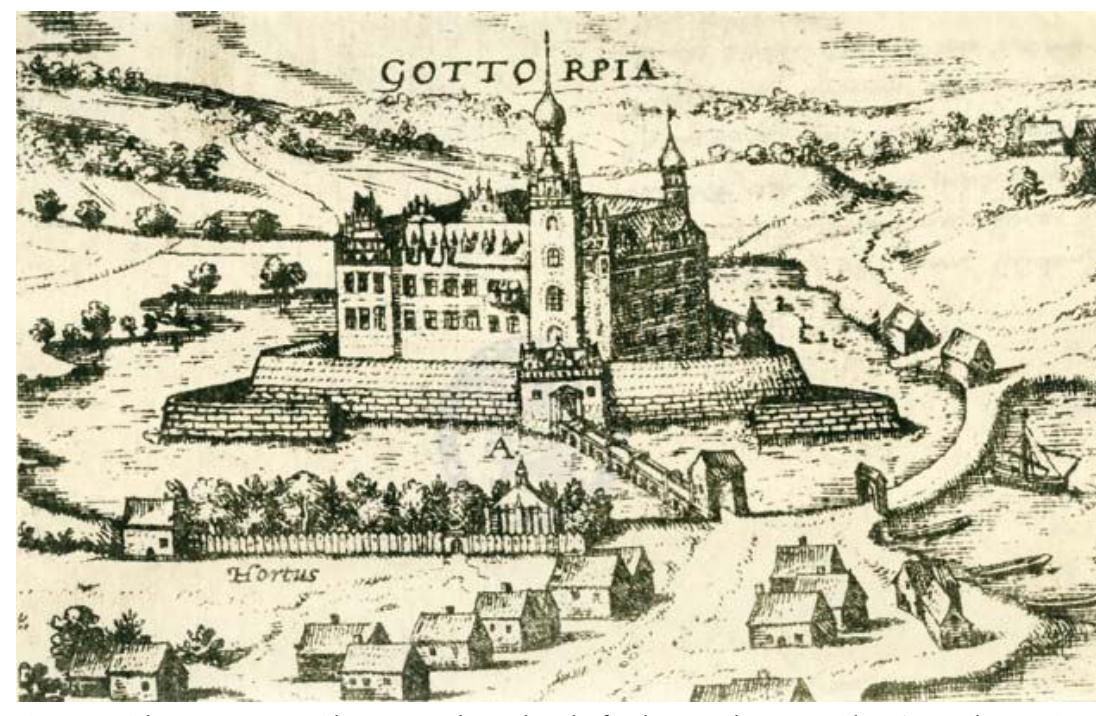

Gottorp Slot, ca. 1584. Slottet var hovedsæde for hertugdømmet Slesvig-Holsten-Gottorp, hoor Johan Adolf regerede 1590-1616. Foto: Arkivet ved Dansk Centralbibliotek for Sydslesvig.

\section{Sagen fra Garding}

Kirketugtssagen fra Garding kendes som nævnt gennem en brevsamling fra provsten Johannes Pistorius (Becker). Ud fra samlingen er det muligt at stykke en handlingsforløb sammen for kirketugtssagen. Peter Thomsen var således blevet beskyldt for hor, og dette krævede ifølge kirkeordinansen en kirkebod i form af et offentligt skriftemål. Gardings præster krævede, at Peter Thomsen skulle stille sig inde i kirken foran menigheden og bede om tilgivelse. Frygten for at blive stillet til skue for offentlighedens fordømmelse fik Peter Thomsen til at nægte at stå til offentligt skrifte. Derfor sendte han et bønskrift til hertug Johan Adolf på Gottorp Slot. Peter Thomsen klagede til hertugen over, at præsterne i Garding nægtede at tage Peter Thomsen, hustruen og børnene til alters fordi løsagtige kvinder beskyldte ham for hor. Præsterne krævede til gengæld, at Peter Thomsen skulle stå til offentlig bod. Dette ønskede Peter Thomsen bestemt ikke. For det første havde han allerede forliget sig med hertugen, hvilket kunne tyde på, at der muligvis var noget om snakken fra de løsagtige kvinder. For det andet ønskede Peter Thomsen ikke, at han og familien skulle hænges offentligt ud af sognepræsten. Dette ville medføre en stor skam for ham i samfundet, hvor den lokale sladder vel kunne blive ondsindet. Derfor bad han hertugen om at pålægge provsten og præsterne i Garding at lade Peter Thomsen gå til alters uden offentlig bod. ${ }^{27}$

Peter Thomsen havde formentligt gode kontakter. Det lykkedes således for ham, at få hertug Johan Adolf over på sin side. Fornemme folk talte Peter Thomsens sag, og hertugen besluttede derfor, at Peter Thomsen ikke behøvede stå til offentligt skriftemål. Det var ganske vist imod kirkelovgivningen, men ikke desto mindre valgte hertug Johan Adolf at sende et brev til den aldrende provst i Ejdersted, Johannes Pistorius (Becker), den 31. maj 1602. I dette brev skrev hertugen, at han

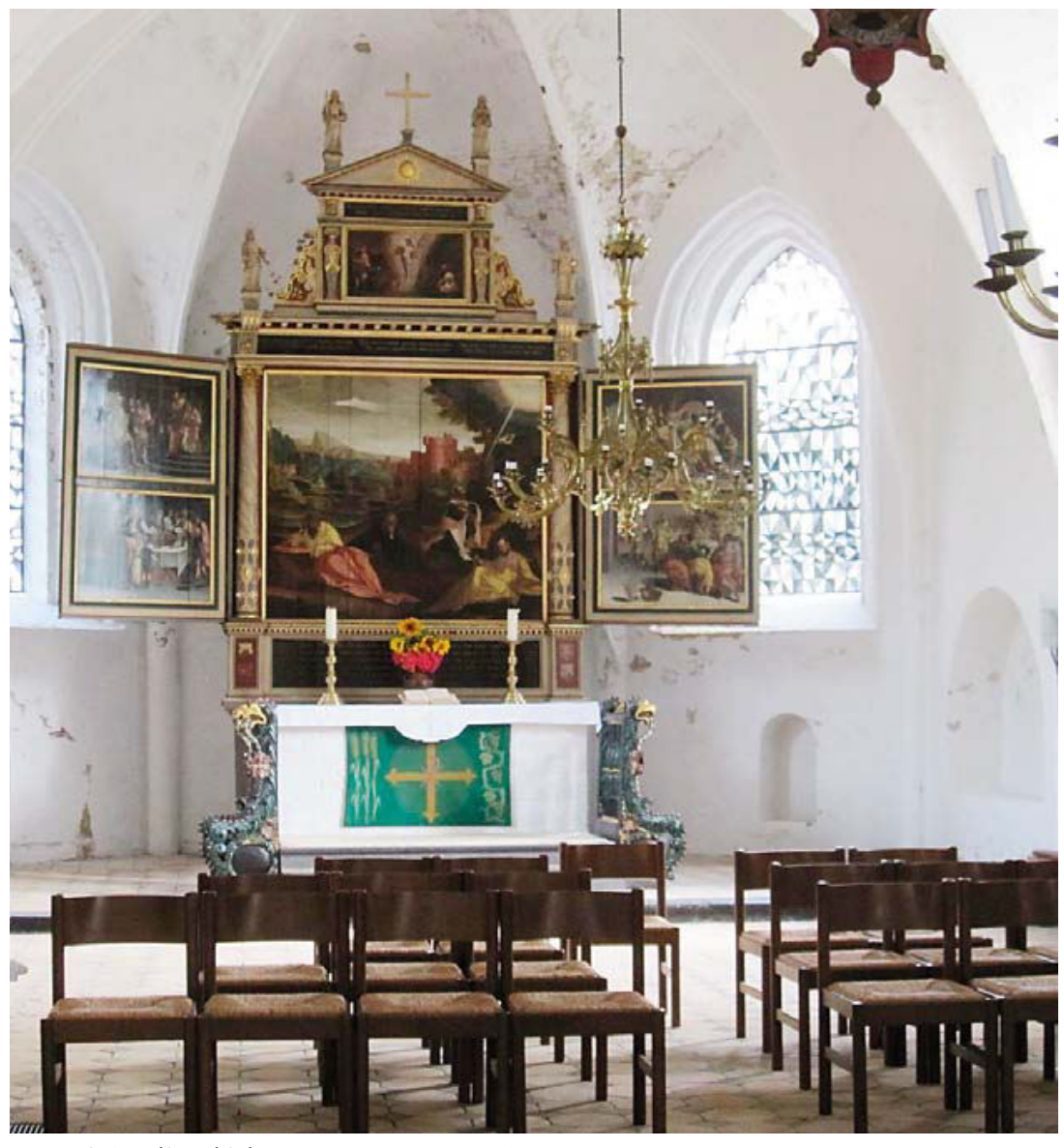

Koret $i$ Garding kirke. Foto: Karsten M. Sørensen. 
ikke ville fravige det, som han på fornemme folks forbøn havde tilsagt Peter Thomsen. Derfor befalede Johan Adolf provsten, at Peter Thomsen ikke skulle pålægges et offentligt skriftemål. Ydermere skulle provsten pålægge præsterne i Garding at lade Peter Thomsen komme til Herrens bord. ${ }^{28}$

Peter Thomsen var således i en situation, hvor han havde gode venner ved hoffet på Gottorp Slot. Sagen om hor synes at være helt afklaret med hertugen, og nu skulle præsterne blot makke ret. Provst Johannes Pistorius (Becker) reagerede naturligvis på denne hertugelige befaling, som han i første omgang adlød. Af det tredje dokument i brevsamlingen fremgår det, at Pistorius den 8. juni 1602 var i Garding, hvor han formanede præsterne om at rette sig efter hertugens befaling.

De to præster i Garding, hovedpræsten Peter Aurifaber (Goldschmidt) og kapellanen Sebastian Meier udbad sig dog otte dages betænkningstid. De var ikke tilfredse med, at hertugen på denne vis ville fravige kirkelovgivningen. Inden for de otte dages betænkningstid blev Sebastian Meier sendt til Husum, hvor han mødtes med hertugdømmets generalprovst, Jacob Fabricius den Ældre, for at drøfte sagen. En generalprovst var at regne som en biskop i hertugdømmet SlesvigHolsten-Gottorps område. I mellemtiden anede Peter Thomsen uråd, og han kontaktede derfor, inden præsternes otte dages betænkningstid var udløbet, hoffet ved Gottorp Slot igen. Peter Thomsen havde ikke i sinde at lade præsterne få en fordel i sagen, og endnu engang lykkedes det for ham at få et nyt mandat fra hertugens hånd. ${ }^{29}$

På dette tidspunkt fornemmer man, at sagen er ved at ændre karakter fra at være en lokal teologisk sag til at blive en politisk og principiel sag. Den 13. juni 1602 sendte Garding-præsten Peter Aurifaber (Goldschmidt) et brev til provst Johannes Pistorius (Becker). Det fremgår af brevet, at kapellanen Sebastian Meier var vendt tilbage fra mødet i Husum med generalprovst Fabricius. Jacob Fabricius den Ælldre kendte på dette tidspunkt ikke selv til hverken sagen eller til hertugens dispensation og overbærenhed. Fabricius gav dog udtryk for, at hvis han var blevet spurgt til råds af hertugen ville han have modsat sig et så ugudeligt menneskes forehavende. Fabricius rådede derfor Garding-præsterne til at indsende et bønskrift og et skriftligt forsvar via provsten. Hertil lovede Fabricius at yde bistand, hvis hertugen afkrævede ham sin mening om sagen. ${ }^{30}$

Det står efterhånden klart, at der ikke er enighed omkring håndteringen af denne sag mellem gejstligheden og hertugen af Gottorp som kir- kens øverst ansvarlige. Præsterne i Garding fulgte Jacob Fabricius den Ældres råd, og den 15. juni 1602 sendte de deres bønskrift og forsvar. Skriftet blev stilet til ministeriet på Gottorp. Præsterne tog fat på mange sider af sagen, hvor det klart fremgik, at de betragtede Peter Thomsen som en ugudelig person, hvis sjæl var i fare. Først og fremmest undrede præsterne sig over, hvorfor Peter Thomsen falskt beskyldte dem for ikke at ville lade ham komme til alteret. Intet kunne, ifølge præsterne, være mere forkert, og det var Peter Thomsen udmærket klar over. Præsterne skrev, at de både i almindelighed, fra prædikestolen og skriftligt påtalte Peter Thomsens ryggesløse levned $\mathrm{i}$ indland og udland, og de formanede ham til bod og bedring. Ved de sidste visitatser nævnte præsterne ham ved navn som en foragter af Guds ord og sakramenterne. I de 16 år han havde boet i Garding, var han kun kommet til alters én gang, og siden da var han i det hele taget kun sjældent eller næsten aldrig kommet i kirken. Præsterne ville derfor ikke gøre sig medskyldige i Peter Thomsens synd ved at give ham en privat eller offentlig absolution og derefter give ham nadveren, da han hverken ville erkende eller bekende sin synd. Peter Thomsen fremviste ingen spor af sand bodfærdighed eller omvendelse. De to præster påberåbte sig derfor den hellige bibel og landets kirkeordning, og de bad hertugen om at ændre sin hidtidige holdning og erklære præsterne for at være uden skyld. Det ville skade deres personlige samvittighed, hvis de tog manden til alters uden offentlig bod. ${ }^{31}$

Dette bønskrift og forsvar er naturligvis en ensidig vinkel på sagen. Peter Thomsen bliver stillet $i$ et meget dårligt lys som ugudelig. I fald dette er et sandt billede af borgeren fra Garding, er det forståeligt, hvorfor præsterne ikke vil lade ham komme til alters. Der kan dog også stilles kritiske spørgsmål til dette forsvarsskrift, for det fremgår også, at Peter Thomsen muligvis mere eller mindre retfærdigt kan have følt sig forfulgt af præsterne, som ved flere lejligheder har udpeget ham ved navns nævnelse. Dette er sket både fra prædikestolen og skriftligt samt i forbindelse med provstens visitatser. Baseret på dette er det vel forståeligt, hvorfor Peter Thomsen ikke har haft lyst til at lade præsterne give ham et offentligt skriftemål. Ikke desto mindre var lovgivningen omkring dette som nævnt helt klar i kirkeordinansen. Præsterne havde retten på deres side, da de krævede en kirkebod via et offentligt skriftemål for Peter Thomsen, inden han kunne modtage nadveren ved alteret.

Desværre for præsterne kunne andre forhold være udslagsgivende for sagens gang. Den 17. juni 1602 udsendte hertug Johan Adolf sit nye 
mandat til provst Johannes Pistorius (Becker) på foranledning af Peter Thomsen. Hertugen var vred over sagens gang. Han ville ikke finde sig i ulydighed og påbød på ny præsterne at lade Peter Thomsen komme uhindret til nadveren. Denne gang skete det under trussel om straf og unåde, hvis befalingen ikke blev lystret. ${ }^{32}$

Denne trussel om en hertugelig straf og unåde skræmte øjensynligt de to præster i Garding. Fem dage efter, den 22. juni 1602, var provsten, Johannes Pistorius (Becker) igen i Husum, hvor han talte med generalprovst Jacob Fabricius den Ældre. Pistorius kunne nu meddele, at præsterne på grund af hertugens trusselsbrev og dette ugudelige og voldsomme menneskes uforskammethed havde ladet sig overtale til at give ham nadveren uden forudgående offentlig bod. ${ }^{33}$ Dermed burde sagen være forbi. Præsterne i Garding havde bukket under for den her-

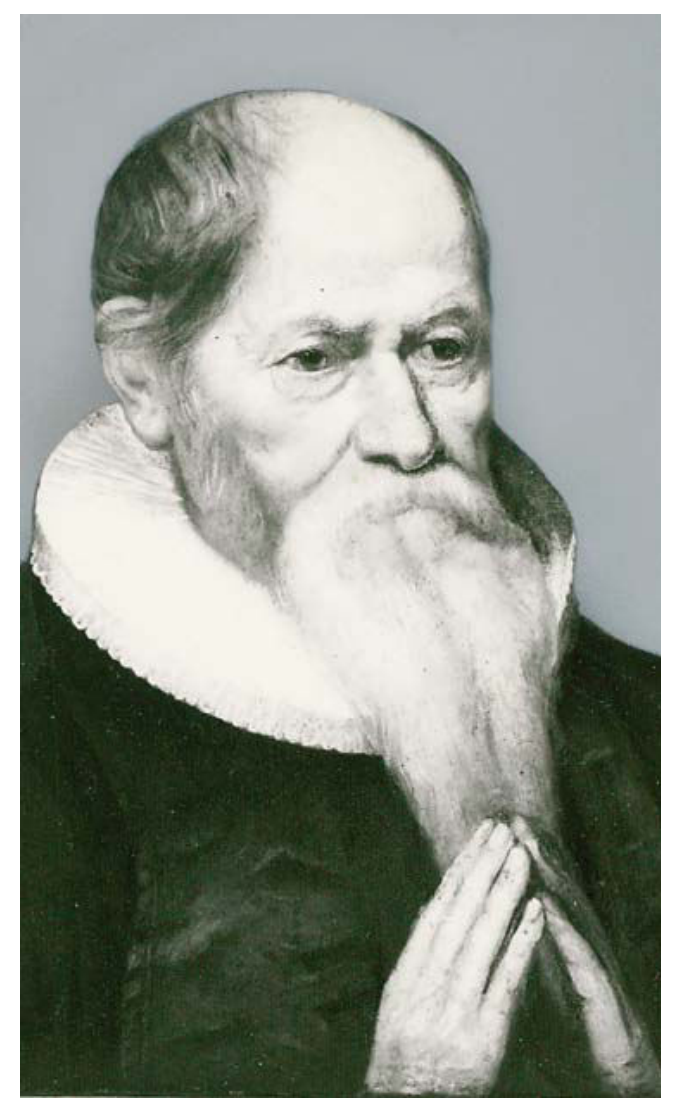

Generalprovst Jacob Fabricius den Aldre.

Foto: Arkivet ved Dansk Centralbibliotek for Sydslesvig. tugelige vilje og ladet en offentligt beskyldt forbryder af det sjette bud omgå kirkeordinansen. Det sidste ord var dog hverken sagt eller skrevet i sagen.

Generalprovsten Jacob Fabricius den Ældre overtog herefter sagen, der havde udviklet sig i en rigtig kedelig retning for gejstligheden. Fabricius gik derfor selv til hertugen for at få denne sag afsluttet korrekt. Generalprovsten må have været stærkt overbevisende over for hertugen. Efterfølgende udsendte Johan Adolf to nye skrivelser, der skulle oplæses for hele menigheden fra prædikestolen, dateret den 24 . juni 1602. Hertug Johan Adolf bekendtgjorde, at Peter Thomsen skulle være fritaget for det offentlige skriftemål, men at dette var et særligt tilfælde, som ikke skulle indbyde til en tilsidesættelse af disciplinen i kirken. Fra prædikestolen fik borgerne i Garding således hertugens ord fra præsten Peter Aurifabers (Goldschmidt) mund. I erklæringen fra hertugen erkendte han, at det i sognet var velkendt, at en af sognets indbyggere, Peter Thomsen, havde forbrudt sig over for Gud og den kristelige menighed med en offentlig synd. Dermed var han skyldig over for både dette hertugdømmes kirkeordning og denne kirke, hvilket krævede et offentligt skriftemål for at forsone sig med Gud og menighed. Nu lå landet imidlertid således, at Peter Thomsen havde gjort sig fortjent til den hertugelige nåde, og hertugen havde derfor givet tilladelse til altergang uden skriftemål, hvilket hertugen flere gange havde påbudt præsterne.

Peter Aurifaber (Goldschmidt) var formentligt godt tilfreds med, at han her kunne oplæse hertugens ord om, at det ikke var præsternes beslutning, men hertugens. Yderligere oplæste han, at dette var et særligt tilfælde, som ikke skulle efterfølges af andre. Hertugen afsluttede sin erklæring med håbet: "Den barmhjertige Gud give dette vort sognebarn og os alle et bodfærdigt hjerte, sand tro og en retskaffen forbedring af vort levned for Kristi skyld. Amen." 34

Erklæringen fra hertug Johan Adolf skulle præsten således læse op for menigheden i Garding kirke fra prædikestolen. Den var vel nærmest et forsvar for præsterne. Skriftet pointerede, at ingen skulle mene, at præsterne selv ordnede det således, eller understå sig med at følge Peter Thomsens eksempel. Dette dokument fik Jacob Fabricius den Ældre hertugen til at udsende af to vigtige grunde. For det første var det vigtigt, at menigheden forstod, hvorledes det ikke var præsternes egen beslutning, at Peter Thomsen blev fritaget for den offentlige kirkebod og skriftemål, men at det derimod var en særlig beslutning, som her- 
tugen havde truffet. Det andet formål var afledt af det første. Det var yderst vigtigt at pointere, at der her var tale om en enlig svale. Disse sager skulle ikke gentage sig. Hvis dette ikke blev gjort helt klart, var der en reel risiko for, at kirkedisciplinen mistede sin grobund i samfundet, og det var hverken hertug Johan Adolf eller generalprovst Jacob Fabricius den Ældre interesseret i. Dette kunne i yderste konsekvens skabe kaos, hvis befolkningen fik ind i hovedet, at de kunne opføre sig som de ville.

Det sidste dokument i kirketugtssagen er en skrivelse fra Gardingpræsten Peter Aurifaber (Goldschmidt), der den 30. juni 1602 anmoder provsten Johannes Pistorius (Becker) om at sende hertugens strenge skrivelse mod præsterne for at kunne imødegå beskyldninger om rådvildhed, mangel på fasthed, karakterløshed og ubesindighed fra andre præster. ${ }^{35}$ Sagen har med andre ord stillet Peter Aurifaber (Goldschmidt) og Sebastian Meier i et dårligt lys i andre gejstliges øjne, hvilket de naturligt nok gerne vil kunne forsvare sig mod ved at fremvise den hertugelige ordre. Det må da også siges at have været en uheldig sag for gejstligheden i Garding, hvor en velkendt synder vandt en kirkelig sag over den lokale gejstlighed ved at inddrage den verdslige øvrighed. Det er dog også en sag, der viser en række ting omkring et emne, der muligvis er noget mere kompliceret end ved første øjesyn, konfessionaliseringens kirkedisciplin. For at forstå dette må vi se på, hvilke impulser det var, der prægede 1500- og 1600-tallets kirkepolitik.

\section{Kirkehistorien kort fra reformationen til 1650}

Hertugdømmet Slesvig fik en fremskudt plads i reformationens forløb, hvilket i særlig grad skyldtes den unge hertug Christian. I 1521 overværede Christian den tyske rigsdag i Worms, hvor Luther over for den tyske kejser nægtede at tilbagekalde sin religiøse opfattelse. I 1525 fik hertug Christian af sin far, Frederik 1., konge af Danmark og hertug af Slesvig og Holsten, overladt Haderslev amt og Tørning len til underhold. Hertug Christian påbegyndte her sin reformation, der kulminerede i 1528, hvor han med de såkaldte Haderslev-artikler fik alle præster til at aflægge en ny luthersk embedsed til sig som fyrste i spidsen for en luthersk fyrstekirke. ${ }^{36}$

Selve reformationen blev dog først officielt gennemført i kongeriget efter store politiske stridigheder og borgerkrigen Grevens Fejde, hvor hertug Christian vandt sig den danske kongetrone i 1536. Følgerne blev blandt andet, at den middelalderlige kirke blev omdannet til en luthersk fyrstekirke. Fremover var det fyrsten, der var kirkens overhoved, og det var i sidste instans fyrstens ansvar, at befolkningen modtog den rette gudstjeneste. Fyrsten havde ansvaret for gejstligheden og folkets tro. ${ }^{37}$

Grevens Fejdes sejrherre, Christian 3. lod i 1537 udarbejde en kirkeordinans i sin lutherske højborg Haderslev. Meningen var, at den skulle gælde for alle hans riger og lande - herunder selvsagt hertugdømmerne Slesvig og Holsten. Det slesvig-holstenske ridderskab modsatte sig imidlertid dette, og i Slesvig blev den katolske biskop Gottschalk Ahlefeldt siddende på sin bispestol på trods af krigens udfald, dog med begrænsede beføjelser. I 1539 blev 1537-ordinansen revideret for Danmark, men således ikke for hertugdømmerne.

Først efter biskop Ahlefeldts død i 1541 kunne Christian 3. indsætte en protestantisk biskop i Slesvig, der fik til opgave at udforme den slesvig-holstenske kirkeordinans i samarbejde med reformatoren Johan Bugenhagen. Resultatet forelå i $1542 .{ }^{38}$ Kirkeordinanserne udstak retningslinjerne for udøvelsen af den lutherske tro. Disse blev løbende suppleret af forskellige tilføjelser i de følgende århundreder.

I denne tidlige periode med lutheranismen var der flere udlægninger, der kom til at præge samfundet. Ortodoksien dominerede således fra slutningen af 1500-tallet til engang i anden halvdel af 1600-tallet. Baggrunden var fremkomsten af en voksende statslig centralmagt, der blandt andet byggede på den opfattelse, at rigets velfærd afhang af folkets gudsfrygt og moral. Det gjaldt om at sikre rettroenhed i stat og kirke. Folk og rige skulle gøres til én kristen menighed gennem disciplineringsforordninger og kirketugt således, at riget ikke påkaldte sig Guds straf. ${ }^{39}$ Det var ikke tilfældigt, at kong Christian 4.'s valgsprog var "Regna Firmat Pietas" (Fromhed styrker rigerne).

Ortodoksien blev præget af et væld af offentlige forordninger, der opsatte rammer og retningslinjer for kirkelivet under statsmagtens opsyn og kontrol. Kirkebøgerne tjente blandt andet som et middel for gejstligheden til at holde et opsyn med menighederne. Dette skal ses i sammenhæng med den teologiske udlægning af Luthers lære i første halvdel af 1600-årene. Dybt forankret i denne tids stats- og kristendomsopfattelse lå det, at rigets velfærd afhang af folkets gudsfrygt og moral. ${ }^{40}$ Derfor var det vigtigt at sikre, at menighederne førte et gudfrygtigt liv, mens synd skulle straffes inden Guds vrede blev vakt. Dette var baggrunden for den store mængde af forordninger, smålove og anvisninger som 
blev udsendt i 1500-tallet og første halvdel af 1600-tallet for at regulere den religiøse kirkebrug omkring blandt andet dåben, vielsen, nadveren og det åbenbare skriftemål.

Der var tale om en opdragelse af befolkningen til at blive gode kristne borgere - og dermed gode lydige undersåtter. Befolkningen skulle deltage i de religiøse ceremonier, og præsten skulle holde opsyn med dette. Efterhånden fik kirkeværgerne og præstens særlige medhjælpere også pligt til at meddele det til præsten, hvis de erfarede, at personer i sognet førte et syndigt liv. Herefter havde både præst og værge pligt til at rette op på det syndige liv. Lykkedes det ikke skulle de bringe sagen videre til provsten, og i sidste instans til den civile øvrighed.

Dette er den centrale del af konfessionaliseringtanken, når vi bevæger os ind i selve kirkerummet - øvrighedens opdragelse af befolkningen. I en ortodoks tankegang var denne opdragelse nødvendig, hvis staten skulle fungere. Dette var baggrunden for et stort antal forordninger i løbet af 1600-tallet vedrørende befolkningens vaner i forbindelse med gudstjenesten. Det blev gentagne gange indskærpet, at man ikke måtte nyde $ø l$, vin eller brændevin om søndagen inden og under gudstjenesten.

Sagen fra Garding fandt sted meget tidligt i denne periode. Slesvig var på dette tidspunkt ikke et ensartet kirkeligt område, hvilket skyldtes hertugdømmets verdslige opdeling med flere hertuger. De to regerende hertuger var den danske konge og hertugen af Gottorp. I de kongelige dele var de kongerigske danske forordninger gældende, mens det gottorpske område fik et særpræg midt i ortodoksien, da hertug Johan Adolf åbnede op for en calvinistisk kirkepolitik. Hertug Johan Adolf blev præget af calvinismen under sin opdragelse hos onklen, landgreve Wilhelm 4. af Hessen. Efter sin tiltræden som hertug på Gottorp Slot medbragte hertug Johan Adolf såkaldte kryptocalvinistiske træk. Det kom blandt andet til udtryk i en strengere varetagelse af kirketugten. Der var et ønske om at komme tidens rå sæder og moralske forfald til livs. Hertugen var især efter voldsforbrydelser og forbrydelser mod det sjette bud - hor og ægteskabsbrud. ${ }^{41}$

I begyndelsen af 1600-tallet blev Johan von Wouwern ansat som gottorpsk kirkepræsident - en ny stilling, der skulle gennemføre calvinismen. I 1609 fik præsterne mundkurv på gennem udstedelsen af en forordning, hvori præsterne blev forbudt at nævne navne eller fordømme og skælde ud på personer fra prædikestolene. Calvinismen blev dog hovedsageligt et fænomen ved hoffet på Gottorp Slot, da der i befolkningen var en væsentlig modstand mod en ændring af den traditionelle kirkeordning. ${ }^{42}$ Efter hertugens død i 1616 blev den ældre kirkepolitik genoprettet $\mathrm{i}$ de gottorpske dele, om end ikke i så streng en grad som $\mathrm{i}$ kongeriget. Der rådede i stedet en vis grad af religiøs tolerance. ${ }^{43}$

Med tanke på at hertug Johan Adolf havde kryptocalvinistiske træk og gik ind for en strengere varetagelse af kirketugten, er det jo noget selvmodsigende, hvordan han valgte side i kirketugtssagen fra Garding til fordel for synderen Peter Thomsen, men det kan der have været gode grunde til for en relativt ny hertug i en ombrydningstid.

\section{Sammenhænge i kirkebodssagen fra Garding}

Når kirkebodssagen fra Garding betragtes med 1600-tallets kirkepolitik i baghovedet kan det virke besynderligt, at sagen udviklede sig som den gjorde. Konfessionaliseringen taler om en fælles forbindelse mellem kirke og fyrste, der arbejdede sammen mod det samme mål. Befolkningen skulle opdrages til at være gode kristne borgere og undersåtter. Et middel til dette var at bruge kirketugten, når befolkningen overtrådte reglerne. På trods af dette udviklede denne sag sig ikke i en fælles retning for kirke og fyrste. Hertugen valgte at støtte synderen og true gejstligheden med straf, hvis de ikke lystrede. Det er tydeligt i denne sag, at personlige holdninger og formål blandt de involverede $\mathrm{i}$ den grad har været udslagsgivende for handlingsforløbet.

Der var allerede som udgangspunkt et modsætningsforhold mellem de gejstlige og hertugen i denne sag. Præsterne i Garding og generalprovsten tilhørte den ortodokse lutherdom, mens hertugen var præget af calvinismen. Dette misforhold burde dog ikke være årsagen til en strid i dette tilfælde. Calvinismen så anderledes på nadveren end ortodoksien, men begge havde et stort fokus på kirketugten. Hertug Johan Adolf udstedte selv flere forbud, der som nævnt skulle komme tidens rå sæder og moralske forfald til livs, herunder især voldshandlinger og ægteskabsbrud. ${ }^{44}$ Peter Thomsen stod netop tiltalt for hor uden for ægteskabet. Sagen burde dermed være helt lige til. I Garding fandtes en borger, som var en kendt forbryder af det sjette bud. Præsterne havde gennem længere tid søgt at tale ham til rette, men uden held, og nu stod han offentligt anklaget for hor. Borgeren ønskede imidlertid at gå til alters med sin familie for at søge nadveren. Dette kunne præsterne naturligt nok ikke tillade, da det var imod kirkelovgivningen, og det kunne bringe alle til fortabelse. Kirkelovgivningen krævede først et offentligt skriftemål, hvor synderen angrede og bad om tilgivelse, 
da ingen måtte modtage nadveren med et urent hjerte. Et offentligt skriftemål kunne dog være forbundet med en hel del skam i forhold til sognets menighed, hvor ens synder blev stillet offentligt til skue. Via personlige forbindelser til hoffet ved Gottorp afklarede Peter Thomsen sin sag med hertugen. Der kan vel have været tale om en tjeneste eller måske en pengeafgift til hertugen. Hvorom alting er, hertugen godtog dette og fritog i sin egenskab af kirkefyrste Peter Thomsen for at skulle stå til offentlig skrifte.

Dette gik dog imod præsternes samvittighed, og de kæmpede for deres sag. De risikerede ikke alene, at Peter Thomsen blev fortabt, de risikerede også både deres egen og deres menigheds fortabelse over for Gud. Præsternes sag stod dog ikke til at vinde. Hertugen ville under ingen omstændigheder lade nogen af sine undersåtter sætte sig op mod hans ordrer. Dette fremgår klart af den skrivelse, som skulle oplæses i kirken som afslutning på sagen. Denne sag handlede formentligt om hertugens autoritet som kirkefyrste og hertug. Sagen fandt sted på et tidspunkt, hvor hertug Johan Adolf i øvrigt kæmpede for at centralisere hertugmagten og indføre en arveret til hertugtitlen. Det sidste blev gennemført i 1608, hvorefter førstefødselsretten skulle afgøre arvefølgen i det gottorpske hertugdømme i stedet for, at det slesvig-holstenske ridderskab skulle vælge hertugen.

Det var vigtigt for både kirke og hertug, at befolkningen blev opdraget og disciplineret, men der kunne tydeligvis være undtagelser, som blev bestemt af kirkefyrsten. Herefter var det af største vigtighed, at der ikke blev sat spørgsmålstegn ved dennes beslutning. Det var dog samtidig vigtigt at understrege for befolkningen i øvrigt, at der kun var tale om et særligt tilfælde. Disciplineringen og opdragelsen fortsatte. Denne sag kan således godt ses i lyset af konfessionaliseringen, men ikke på den traditionelle måde med enighed omkring målet. Den viser også, at gejstligheden tillagde kirketugten dybe religiøse hensigter. Kirketugten var ikke blot et redskab, som staten kunne gøre brug af. Statsmagtens konsolidering handlede også om en konsolidering af fyrsten som kirkefyrste, hvor fyrstens befalinger ikke var til diskussion. I dette tilfælde vejede denne del således tungere for hertug Johan Adolf end hensynet til kirkeordinansens bestemmelser.

Hertug Johan Adolf og gejstligheden i hertugdømmet med Jacob Fabricius den Ældre i spidsen fortsatte deres stridigheder omkring teologiske spørgsmål inden for den slesvigske kirke. Stridighederne fortsatte i 1600'erne og resulterede i 1610 endelig i, at Jacob Fabricius den Ælldre blev afsat og erstattet af den calvinistiske Philip Cæsar af Hessen. Efter hertug Johan Adolfs død i 1616 blev Cæsar afsat og Jacob Fabricius den Ældre genindsat. ${ }^{45}$ Denne sag var blot én ud af mange, der var med til at forværre forholdet mellem den kryptocalvinistiske hertug og den ortodokse generalprovst.

\section{Afsluttende bemærkninger}

Efter reformationen overtog eller inddrog fyrsten kirkens projekt, og det blev et fælles projekt om at skabe gode lydige lutherske undersåtter $i$ fyrstens rige. En fyrste kunne imidlertid have forskellige grunde til at yde særlige privilegier i forhold til lovgivningen, som i dette tilfælde, hvor Peter Thomsen gennem en kontakt til Gottorp Slot fik lov til at slippe for en formentlig pinlig og offentlig irettesættelse af præsterne i form af et offentligt skriftemål. Præsterne brokkede sig naturligt nok over dette, da reglerne var ganske klare. Uheldigvis for præsterne var hertugen ikke til sinds at lade nogen af sine undersåtter gå imod en hertugelig ordre.

Magtpolitisk havde præsterne i Garding ikke en jordisk chance mod en kirkefyrste i en sag, der kom til at blive principiel frem for teologisk. Der er mindst tre væsentlige træk ved denne sag. For det første kunne kirkefyrsten øjensynligt fritage personer fra kirketugten. I dette tilfælde var det desuden vigtigt for hertugen at præsterne under ingen omstændigheder måtte sætte spørgsmålstegn ved hertugens autoritet og beslutninger. For det andet viser eksemplet, at gejstligheden tog kirketugten endog meget alvorligt. Dette var lige fra præsterne til provsten og generalprovsten. I sidste instans måtte gejstligheden bøje sig for kirkefyrsten, men det skete kun under trusler og siden med en vis form for oprejsning. For det tredje viser eksemplet, at man skal vare sig for at se den gejstlige og den verdslige øvrighed som en fælles enhed efter reformationen, andre forhold kunne afgøre beslutningerne. Denne sag indbyder derfor til flere spørgsmål omkring forholdet mellem kirkefyrsten og gejstligheden, og den indbyder til nye og flere spørgsmål om konfessionaliseringens karakter. 


\section{KILDER OG LITTERATUR}

Alwast, Jendris: "Das landesherrliche Kirchenregiment zu Gottorf (1544-1721) ci Verein für Schleswig-Holsteinische Kirchengeschichte: Schleswig-Holsteinische Kirchengeschichte. Band 4: Orthodoxie und Pietismus, Neumïnster 1982, doxie und Pietismus, Neumünster 1982,

Appel, Charlotte \& Fink-Jensen, Morten Når det regner på præsten. En kulturh storie om sognepræster og sognefolk 1550 1750, Aarhus 2009.

Appel, Hans Henrik: Tinget, magten og æren. Studier i sociale processer og magtre lationer $i$ et jysk bondesamfund $i$ 1600-tallet, Odense 1999

Arends, Otto Fr.: Gejstligheden i Slesvig og
Holsten. Fra Reformationen til 1864. Bind Holsten. Fra Reformationen til
1-3. København 1932-1933.

Bach-Nielsen, Carsten: "1500-1800" i: Bach-Nielsen, Carsten \& Ingesman, Per (ed.): Kirkens historie. Bind 2, København 2012. s. 19-381.

Bisgaard, Lars: "Det religiøse kongefællesskab 1400-1600" i: På sporet af staten - Dansk statsdannelse mellem middelalder og enevalde. Den jyske historiker $n r$. 116 2007, s. 120-140.

Christensen, Mogens: "Kirke og statsdannelse 1536-1660". i: På sporet af staten. og enevalde. Den jyske Historiker nr. 226 2007, s. 141-164.

Corpus Constitutionum Daniæ: Forordninger, recesser og andre kongelige breve, Danmarks lovgivning vedkommende, 1558 1660, Bind 1-6. Udgivet ved V. A. Setil dansk historie, København 1887-88 (CCD)

Dansk Biografisk Leksikon (http://www. denstoredanske.dk/Dansk_Biografisk_Leksikon)

Die Schleswig-Holsteinische Kirchenordnun von 1542. Udgivet ved Walter Göbell under medvirken af Annemarie Hübner \& Hans-Joachim Ramm. Schrifte des Vereins für Schleswig-Holstein sche Kirchengeschichte, rk. I, bd. 34 Neumünster 1986. (SHK 1542)

Fussing, Hans H.: "Altergangsstridigheder i Vestervig 1632" i: Kirkehistoriske Samlinger. Række 6, bind 3, 1939 , 184-189.
Fussing, Hans H.: "En kirketugtssag fra Holger Ronsenkrantz' gods" i: Kirkehistoriske Samlinger. Række 7, bind 1 1952, s. 458-461.

Gregersen, H. V.: Slesvig og Holsten før 1830. København 1981.

Gregersen, H. V.: Reformationen i Sønderjylland. Skrifter udgivne af Historisk Samfund for Sønderyylland nr. 63. Aabenraa 1986.

Göbell, Walter: "Die Anfänge der Reformation in Dänemark und in den Herzogtümern Schleswig und Holstein unter Herzog und König Friedrich I" i Verein für Schleswig-Holsteinische Kirchengeschichte: Schleswig-Holsteinische Kirchengeschichte. Band 3: Reformation, Neumünster 1982, s. 9-34.

Henningsen, Lars N.: "Lutherske kirker mellem dansk og tysk. Omrids af Sønderjyllands kirkehistorie efter Reformationen" i Sønderjyske årbøger 2004, s. 133-170.

Henningsen, Lars N.: "Mønsterregion i det danske monarki 1721-1814" i: Schultz Hansen, Hans, Henningsen Lars N. \& Porskrog Rasmussen, Carsten (ed.): Senderjyllands Historie 1 Indtil 1815, Aabenraa 2008, s. 333-468 Hoffmann, Erich: "Der Sieg der Reformation in den Herzogtumern Schleswig Holsteinische Kirchengeschichte Schleswig-Holsteinische KirchengeschichSchleswig-Holsteinische Kirchengeschich-
te. Band 3: Reformation, Neumünster $1982 \mathrm{~s} .115-184$.

Ingesman, Per: "Kirke, stat og samfund i historisk perspektiv" i Knudsen, Tim (ed.): Den nordiske protestantisme og velfxrdsstaten, Århus 2000, s. 65-86.

Ingesman, Per: "Fromhed styrker rigerne i Carsten Bach-Nielsen (et. al.) (ed.) Danmark og renæssancen 1500-1650 København 2006. s. 130-145.

Jacob Fabricius den Yngres Optegnelser 1617 1644. Udgivet ved A. Andersen. Skrifter, udgivne af Historisk Samfund for Sønderjylland. Nr. 32. 1964.

Jespersen, Mikkel Leth: "Kirkeorganisation og konfessionalisering mellem fyrstestat og lokalsamfund i SlesvigHolsten-Haderslev 1544-1580" i Kirkehistoriske Samlinger, 2008, s. 43-83.
Kaufmann, Thomas: Konfession und Kultur. Lutherischer Protestantismus in der Zweiten Hälfte des Reformationsjahrhunderts. Spätmittelalter und Reformation. Neue Reihe, 2006.

Lausten, Martin Schwarz: Kirkens historie Danmark. Pavekirke - Kongekirke - Folkekirke. Århus 1999.

Lausten, Martin Schwarz: Danmarks kirkehistorie. København 2004 (1987).

Lotz-Heumann, Ute: "Confessionalization" i: Whitford, David M. (ed.): Reformation and Early Modern Europe. a guide to research. Truman State University Press 2008, s. 136-157.

Malmstedt, Göran: Bondetro och kyrkoro. Religiös mentalitet $i$ stormakttidens Sverige. Lund 2002.

Petersen, Klaus \& Rode, Hans-Henrik: "Kirke og stat i 1600-tallet" i Kirkehistoriske samlinger. 1995, s. 63-100.

Porskrog Rasmussen, Carsten: "Ét hertugdømme - mange herrer 1544-1720" i Schultz Hansen, Hans, Henningsen, Lars N. \& Porskrog Rasmussen, Carsten (ed.): Sønderiyllands Historie 1 Indtil 1815. Aabenraa 2008, s. 187-332.

Poulsen, Bjørn: "Hertugdømmets dannelse" i Schultz Hansen, Hans, Henningse" i Schultz Hansen, Hans, Henning-
sen, Lars N. \& Porskrog Rasmussen sen, Lars N. \& Porskrog Rasmussen,
Carsten (ed.): Sønderiyllands Historie 1

Indtil 1815. Aabenraa 2008, s. 41-186.

Quattuor Centurix Epistolarum. Provst Johannes Pistorius' Brevsamling 15411605 (1614). udgivet ved A. Andersen. Historisk Samfund for Sønderjylland, 1971. (Pistorius 1541-1605)

Reinhard, Wolfgang: "Zwang zur Konfessionalisierung? Prolegomena zu einer Theorie des konfessionellen Zeitalters" i: Zeitschrift für historische Forschung, 10. 1983, s. 257-277.

Reinhard, Wolfgang:"Reformation, CounterReformation, and the Early Modern State. A Reassessment" i Catholic Historical Review, 75, 1989, s. 383-404.

Reinhard, Wolfoang: "Was ist katholische Konfessionalisierung?" $i$ Reinhard. Wolfang \& Schilling Heinz (ed): Die kathogang $\mathcal{O}$ Schilling, Heinz (ed.): Die katholisches Symposion der Gesellschaft zur lisches Symposion der Gesellschaft zur Les des Vereins für Reformationsgeschichte.
Sabean, David W: Power in the Blood. Popular Culture $\mathcal{E}$ village discourse in early modern Germany. Cambridge 1987 (1984).

Schilling, Heinz: "Confessionalization in the Empire. Religious and Societal Change in Germany between 1555 and $1620^{\prime \prime}$ i: Schilling, Heinz: Religion, Political Culture and the Emergence of Early Modern Society. Essays in German and Dutch History. Leiden, New York, Cologne, Brill 1992, s. 205-245.

Schilling, Heinz: "Confessional Europe" i Brady, Jr., Thomas A., Oberman, Heiko A. \& Tracy, James D. (ed.): Handbook of European History, 1400-1600. Late Middle Ages, Renaissance and Reformation. II. Visions, Programs and Outcomes. Leiden, New York, Cologne, Brill 1995a, s. 641675.

Schilling, Heinz: "Die Konfessionalisierung von Kirche, Staat und Gesellschaft. Profil, Leistung, Defizite und Perspektiven eines geschichtswissenschaftlichen Paradigmas" i: Reinhard, Wolfgang \& Schilling, Heinz (ed.): Die katholische Konfessionalisierung. Wissenschaftlisches Symposion der Gesellschaft zur Herausgabe des Corpus Catholicorum und des Vereins für Reformationsgeschichte, Gütersloh 1995b, s. 1-49.

Schmidt, Heinrich Richard: "Socialdisziplinierung? Ein Plädoyer für das Ende der Etatis Ein Plädoyer für das Ende der schrift $n$ r. 265, 1997, s. 639-682.

Skovgaard, Johanne: "Tidsrummet c 1600-1660" i: Skovgaard, Johanne \& Hjelholt, Holger (ed.): Sønderiyllands historie fremstillet for det danske folk. Bind 3: Tidsrummet c. 1600- c. 1805. Under redaktion af Vilh. La Cour, Knud Fabricius, Holger Hjelholt og Hans Lund bind 3, København 1940-1942, s. 3-152.

Sørensen, Karsten Merrald: Det dynamiske kirkerum. Kirkerummets brug og funktion $i$ hertugdommet Slesvig fra Reformationen til ca. 1800 . Upubliceret ph.d-afhandling. Aarhus Universitet 2013.

Weitling, Günter: Fra Ansgar til Kaftan. Sydslesvig $i$ dansk kirkehistorie 800-1920. Flensborg 2005. 
NOTER

1 Jespersen 2008, s. 59

2 Pistorius 1541-1605. 372 (a-o) s. 312ff. 3 Se eksempelvis Bisgaard 2007; Gregersen 1981; Henningsen 2004; Kaufman 2006, Reineff. Rein, s. 263.; Reinhard 1989, s. 391ff., Reinhard 1995, s. 426 . Schilling 1992, s. 209.; Schilling 1995 s. 641ff.; Schill

4 Jespersen 2008

5 SHK 1542.

6 "Den yegen apenbar Sünde hört ock eine apentlike Absolutio. Wat auers hemelick gescheen ys, dat schal ock hemelick Absoluert werden." SHK 1542, s. $94 / 95$.

7 Reces af den 27. februar 1643 (1.2.18.), CCD., s. $178 \mathrm{ff}$.

8 Appel \& Fink-Jensen 2009, s. 74f

9 Sørensen 2013, s. 112ff.

10 Appel 1999, s. $448 f$ og $458 \mathrm{ff}$.

11 Ingesman 2006, s. 130ff.; Bisgaard 2007b, s. $120 \mathrm{ff}$.

12 Appel 1999; Jespersen 2008, s. 75.

13 Malmstedt 2002

14 Malmstedt 2002, s. 141.

15 Jespersen 2008, s. $76 \mathrm{f}$

16 Appel \& Fink-Jensen 2009, s. 235ff

17 Appel \& Fink-Jensen 2009, s. 235ff.

18 Appel \& Fink-Jensen

20 Sabean 1987, s. 37ff.; Malmstedt 2002, s. $149 \mathrm{ff}$.

21 Se blandt andet Fussing 1939, s. 184ff. Fussing 1952, s. 458ff.; Appel 2009, s.

22 Arends 1932-33. Bd. 1, s. 286.; Arends 1932-33. Bd. 2, s.75.

23 Dansk Biografisk Leksikon, Johanne Pistorius.

24 Jacob Fabricius den Yngres Optegnelser 1617-1644, s. VII-IX

25 Henningsen 2008, s. 126.

26 Skovgaard 1942, s. 3 ff.

27 Pistorius 1541-1605. 372 (a), s. 314

28 Pistorius 1541-1605. 372 (b), s. 314f.

29 Pistorius 1541-1605. 372 (c, e), s. $315 f$.

30 Pistorius 1541-1605. 372 (d), s. 315f.

31 Pistorius 1541-1605. 372 (g), s. 316f

32 Pistorius 1541-1605. 372 (f), s. 316

33 Pistorius 1541-1605. 372 (i), s. 320.

34 "Idt is yw leven Christen und Carspellude bekandt, wat mathen vor düsser mit en düsses Carspels inwohner mit nahmen Peter Thomsen sich mit apenbaren Sünden jegen Gott versündiget und dusse Christliche Gemeine geergert hefft, derwegen he den vermoge dusser Forstendöhme Kerckenordeninge und unser Kercken gebrueck schuldig gewesen were, dorch apenbare Bothe sich mit Gade und dieser Christlichen Gemene wedderumb tho versohnen. Dewile he overst by unserm Gnedigen Fürsten und Herr up ingebrachten Bericht und geschene vorbede so veel erholden, dat uns tho ethliken und underscheetliken mahlen ernstlich befahlen worden, ehn ahne solche apenbare Bothe thom Hochwerdigen Aventmahle thotholaten, hebben wy solchem gehorsam geleistet. Damit nu nemant manck yw edder sunst, alse hedden wy van uns sülvest solches vorgenahmen gedencken, edder ock sich düsses Exempels herna tho gebruken understahen mochte. So hebbe wy solches, wo idt hirumb bewandt unser Christlighen Gemeine, doch mit gnedigem vorwethen und bewilligung unseres Gnedigen Fürsten und Herrn Christlich vormelden willen. De barmhertzige Gott vorlehne düssem unserm hertzige Gott vorlehne düssem unserm Carspelsmanne und uns allen samptlich ein Boothferdich harte, waren $\mathrm{Ge}$ loven und rechtschapene bethering unsers levendes umb Jesu Christi willen Amen." Pistorius 1541-1605. 372 (m, n) s. $321 f$

35 Pistorius 1541-1605. 372 (o), s. 322.

36 Göbell 1982, s. 61ff.; Gregersen 1986, s. $54 \mathrm{ff} ., 118 \mathrm{ff}$.

37 Hoffmann 1982, s. 130ff.; Poulsen 2008 s. $185 f$.

38 Poulsen 2008, s. 185.

39 Porskrog Rasmussen 2008, s. $268 \mathrm{ff}$.

40 Appel 1999, s. 446ff.; Bach-Nielsen 2012 , s. 259ff.

41 Alwast 1984, s. 11ff.

42 Henningsen 2004, s. 140.

43 Gregersen 1981, s. 294ff.; Henningsen 2004 , s. $139 \mathrm{ff}$.

44 Alwast 1984, s. $11 \mathrm{ff}$.

\section{Zusammenfassung}

Anfang des 17. Jahrhunderts kam es in Garding bei Eiderstedt zu einem Streit zwischen dem Bürger Peter Thomsen auf der einen und den örtlichen Pfarrern auf der anderen Seite. Die Pfarrer wollten es nicht zulassen, dass Thomsen zum Abendmahl ging, weil er Ehebruch begangen hatte und sich so gegen das sechste Gebot versündigt hatte. Deshalb sollte er laut Kirchenzucht vor dem Abendmahl öffentlich beichten, wogegen er sich jedoch weigerte. Der gottorfer Herzog Johan Adolf wurde in den Streit verwickelt, er legte es den Pfarrern nahe, Thomsen zu Abendmahl gehen zu lassen. In diesem Artikel wird das Sachverhältnis untersucht mit dem Schwerpunkt auf die Machtverhältnisse zwischen Fürstentum und Kirche wenige Jahrzehnte nach Durchführung der Reformation in Dänemark und in den Herzogtümern.

Mit der Reformation übernahm der Fürst das kirchliche Projekt und es gab so gemeinsame Bestrebungen, im Reich des Fürsten gute lutherische Untertanen zu erziehen. Für den Fürsten gab es verschiedene Gründe für die Privilegien. In diesem Fall vermied Peter Thomsen die vermutlich peinliche Zurechtweisung durch die Pfarrer in Form einer öffentlichen Beichte. Die Pastoren waren damit nicht einverstanden, denn es gab auf diesem Gebiet klare Regeln. Der Herzog ließ jedoch keine seiner Untertanen gegen einen herzoglichen Befehl angehen.

Machtpolitisch hatten die Priester in Garding gegen einen Kirchenfürsten keine Chance, besonders nicht, weil es sich hier um einen Sachverhalt prinzipieller und nicht nur rein theologischer Art drehte. Bei dieser Sache gibt es mehrere bedeutende Punkte. Offensichtlich konnte der Kirchenfürst die Kirchenzucht in bestimmten Fällen aufheben. Für den Herzog war es von großer Bedeutung, dass die Priester seine Entscheidungen und seine Autorität nicht in Frage stellten. Zum zweiten zeigt dieser Fall, dass die Kirchenzucht von den Geistlichen $\bigotimes$ von den Pastoren über den Probst bis hin zum Generalprobst - sehr ernst genommen wurde. Letzten Endes mussten die Geistlichen vor dem Kirchenfürst abbiegen, was aber nur unter Drohungen und später mit gewissen Entschädigungen stattfand. Zum dritten zeigt dieses Beispiel, dass die Geistlichkeit und die weltliche Obrigkeit sich nach der Reformation nicht immer einigen konnten. Hier entstehen oft Fragen über das Verhältnis zwischen Kirchenfürst und Geistlichkeit und Fragen zur Art der Konfessionalisierung. 